九州大学学術情報リポジトリ

Kyushu University Institutional Repository

\title{
The Organizational Aspect of Irrigation Development Project : The Case of Nong Wai Pioneer Agriculture Project
}

Prapertchob, Preeda

Seminar of Econometric Analysis in Agriculture, Faculty of Agriculture, Kyushu University

Tsuchiya, Keizo

Seminar of Econometric Analysis in Agriculture, Faculty of Agriculture, Kyushu University

https://doi.org/10.5109/23841

出版情報：九州大学大学院農学研究院紀要. 31 (1/2)，pp. 159-166，1987-02. Kyushu University バージョン：

権利関係 : 


\title{
The O rganizational Aspect of Irrigation D evelopment Project The Case of $\mathbf{N}$ ong W ai Pioneer Agriculture Project -
}

\author{
Preeda Prapertchob* and K eizo Tsuchiya \\ Seminar of Econometric Analysis in Agriculture, Faculty of Agriculture, \\ Kyushu University 46-07, Fukuoka 812 \\ (Received July 29, 1986)
}

\begin{abstract}
The success of irrigation heavily depends upon the good water management which essentially requires efficient farmer organization. Within the Nong Wai Pioneer Agriculture Project in the northeast of Thailand, there are various farmer organizations and the Nong Wai Agricultural Cooperative Society (NACS) is one of them. It was originally intended to be the single farmer organization in the project area. But the finding from this study shows that the integration of these farmer organizations is not successful and there is still competition among various organizations in rendering the service to farmers. The NACS, as indicated in this paper, largely involves only in the provision of agricultural credit to farmers. In the field of water management the NACS was assigned to collect the operation and maintenance ( 0 and $\mathrm{M})$ fee from farmers and it could perform this function well during the year of study. But without having a strong and definite penalty for those who fail to pay for the fee, the number of members who do not pay for the 0 and $M$ fee is expected to increase. It is recommended by this study that the NACS should play a wider role in water management and agricultural extension activity.
\end{abstract}

\section{INTRODUCTION}

Irrigation has long been considered as the key factor contributing to the success of the agricultural development. But irrigation development is costly and in many cases it is out of reach of the debt-ridden developing countries to carry out the large-scale project for irrigation. Therefore irrigation development projects are now not easy to be implemented and much care is taken before making decision. Generally the feasibility study is performed before implementation of the project and the cost-benefit analysis is done to measure the economic viability of the project. Most $\mathrm{o}^{1}$ these studies are based on the assumption that there is little or no problem about water management and the local farmer's organizations work well. But it is often found that this assumption is not true and the organization turns to be the major constraint for irrigation development in many projects. This study is intended to explore this issue particularly that of the Nong Wai Pioneer Agriculture Project (NWPAP). This project was once designed to achieve and demonstrate rapid integrated agricultural development in the Northeast Region which is the poorest part of the country. The project comprised rehabilitation and improvement of the existing main irrigation and drainage system constructed in the mid 1960s, implementation of land consolidation in the entire

* Department of Agricultural Economics, Faculty of Agriculture, Khon Kaen University, Thailand. 
irrigable area of about 12,000 ha and strengthening of agricultural support services.

\section{METHODOLOGY}

This study was conducted through the literature concerning the institutional aspect of the Nong Wai Pioneer Agriculture Project. The visit and interview of the resource persons concerning the project was done. The emphasis of this study was placed on the qualitative rather than the quantitative one.

\section{RESULT AND DISCUSSION}

\section{Organizational set-up}

During the early days after the area was first irrigated, the Royal Irrigatioin Department (RID) made an attempt to establish the Water User Associations as the farmer's organization to take responsibility in water management in the project area. There were four Water User Associations, the first one was Nam Pong Water User Association, founded in 1969. In all cases these associations have never become active and it failed even the time of establishment. The reason was quite simple. Such an organization was alien to them and its structure was too big and too sophisticated for farmers to handle and manage. The RID who initiated this organization had no good experience for farmer organizational management and as the matter of fact it had not placed much emphasis upon this aspect as compared to the engineering function. Under the new phase of the project where land consolidation was playing the leading role (1975-1981) there was an attempt to revive the farmer body for water management under the new name of Water Users Group (WUG). The purpose of group formation is to let the farmers have their own organization to operate and maintain the on-farm irrigation facilities. At present there are 170 WUGs in the project area. Each group is responsible for about 300-500 rai of the area.

The agricultural cooperative society is the other important farmer organization in the project area. The establishment and supervision of this organization is done by the Cooperative Promotion Department (CPD). The Nong Wai Agricultural Cooperative Society (NACS) was founded in 1977 by partial amalgamation of three local agricultural cooperative societies by selecting only farmers who were in the project area. Unlike the WUGs which are organized by the irrigation canals or irrigated plots, the NACS has the member groups which at present there are altogether 52 which are generally village based. The total members of the NACS are (at March 31, 1985) 2,512 which is about $52 \%$ of the total farm households in the project area (about 4,800 households). The primary function of the NACS is, as same as most agricultural cooperative societies in Thailand, to give the loan to its members. The income of the NACS from th credit activity in $1984-85$ was $837,491.25$ baht or $88.59 \%$ of the total income.

The other farmer organizations in the project area are the various groups organized by the extension agents of the Department of Agricultural Extension (DOAE), namely, Farmer Associations, Housewife Groups, 4-H Groups. These groups are organized in order to facilitate the extension work of the local extension agent (Kaset Tambon-KT). They are organized villagewise but the formal groups are at Tambon level. 
The above mentioned farmer organizations are not at all exhaustive because the other groups organized by other departments out of the Ministry of Agriculture and Cooperatives have not yet included, notably the groups organized by the Community Development officials of the Community Development Department (CDD) of the Ministry of Interior. The other major and relatively important group is the client groups of the Bank for Agriculture and Agricultural Cooperatives (BAAC) which are competitive with the NACS in the field of agricultural credit.

It should be noted from the beginning that the estabishmen of any farmer group was done through the government initiative. Farmers generally have understanding that these groups belong to the government even though some efforts were spent in explaining the philosophy and the role of farmers in each respective groups. The short-cut process and instant establishment of the groups are responsible for such a wrong impression. This affects a lot upon the stability and progress of the groups because without the sense of belonging the group activity and group deliberation cannot be performed. In some cases farmers cannot differentiate one group from the others because only the names are different but their activities are more or less similar. They found that the NACS offered the (cheap) loan to farmers and the farmer association of the DOAE had also the credit program. They were taught about the agricultural techniques from the KT through the farmer associations but in some cases they could learn from the extension officials of RID through WUGs and also from the CPD officials under the NACS. One farmer might become the members of all three organizations but he did not well understand the role of these organizations. He applied for the membership because he was asked to do so by the government officials or village headman. He was probably promised to be given the cheap credit or some farm inputs if he applied as a member.

Having different organizations sometimes confuses farmers not only in terms of the different names but also the policy of each organization. In the old days the RID tried to encourage farmers to grow second crop of paddy while the DOAE promoted the non-rice crops for the dry season. Recently the Dry Season Cropping Committee was formed to coordinate among the organizations and agencies concerned and to make the policy more consistent so far as the dry season cropping was concerned.

There was an attempt to unify all these farmer organizations together under the cooperative umbrella and the NACS was proposed to be only one single institution whereas the WUGs and the agricultural extension groups were under the cooperative. The NACS was entrusted to collect the 0 and $M$ fee from the farmers and it proved to be reasonably sucessful. The number of WUGs which paid the 0 and $M$ fee increased rapidly to 138 groups in 1985/86 (out of the total number of 170 groups). The number of members who paid for the fee was more than 4,000 while about 1,500 members had not paid the 0 and $M$ fee. (The 0 and $M$ fee per rai per year was originally set at 64 Baht for the intensive irrigated area and 54 Baht for the extensive area. It was recently reduced to only one falf of the rate to only 32 Baht and 27 Baht for the intensive and extensive area respectively).

As far as the agricultural extension is concerned, the extension agents have not yet worked closely with the NACS. They have their own program of visit and their own target groups. The NACS wants to initiate the farm guidance program to its members but it cannot afford to employ extra workers for this purpose. The CPD 
which has the separate unit for supervising the NACS has only one official who is responsible for farm guidance or agricultural extension work.

Since the NACS is assumed to play the central role for institutional development of the project area, therefore it is worth considering it in detail.

Table 1. Credit operation and financial position of the NACS.

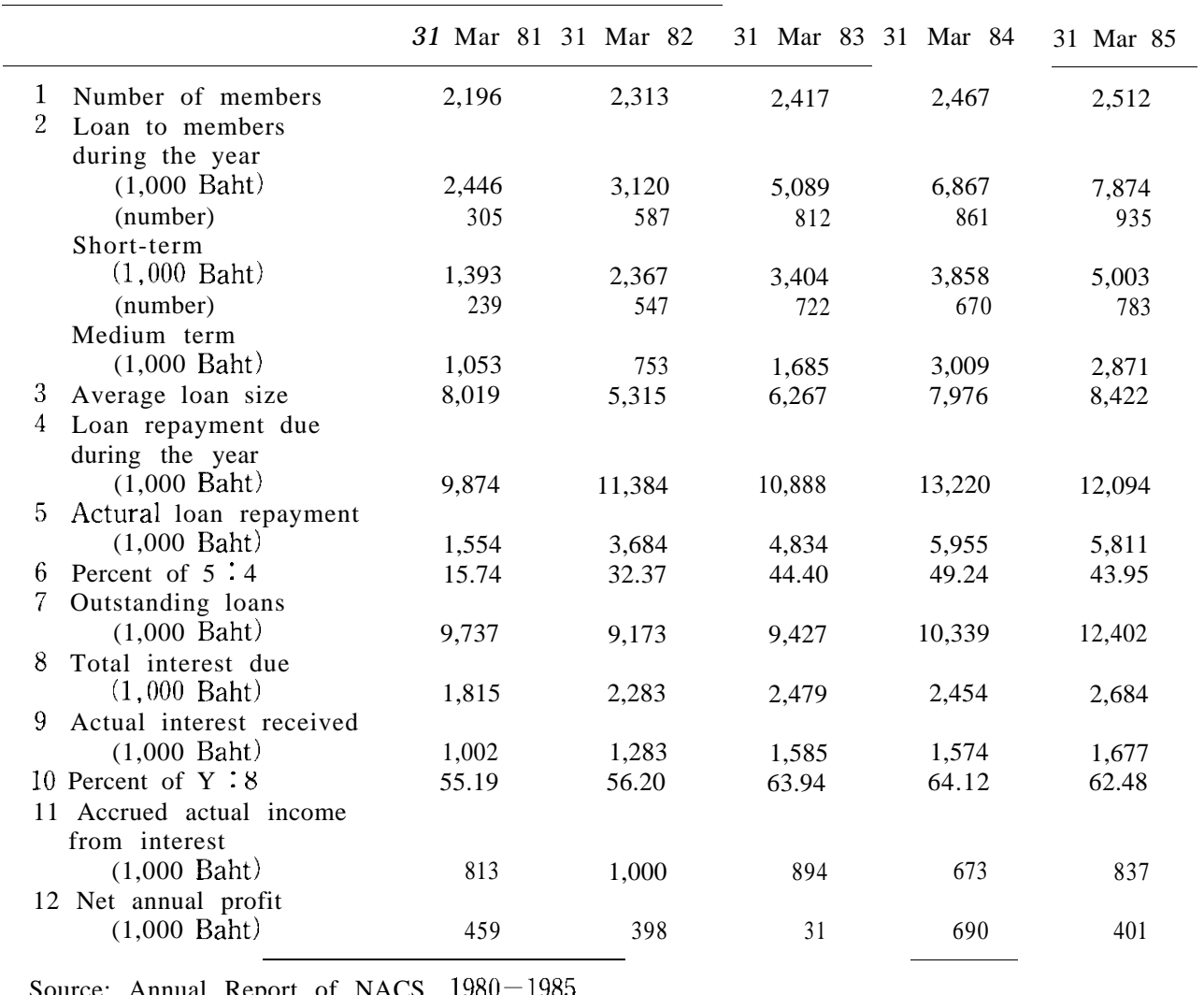

Source: Annual Report of NACS, 1980-1985.

\section{Performance of the Nong Wai Agricultural Cooperative Society (NACS)}

As mentioned earlier, the NACS members are only one-half of the total farm households in the project area. Once it was planned to increase the number of its members about 300 annually but it was found that the recent trend rather levelled off. One of the reasons why the rest do not apply for the membership is because many of them are already the members of the BAAC and it is against the rule of being the members for both institutions concurrently. Since the BAAC lingered on its effort to fade out of the project area and its members also found more convenient to deal with the BAAC than the NACS. But the actual reason should be that the NACS itself cannot afford for many more members because the ceiling of loan from BAAC is limited only to 12 million Baht and this ceiling cannot be raised because the repayment rate has not reached a satisfactory level. The new members, if they had been 
recruited, they would not have had the chance to get the loan from the NACS. The major economic activity of the NACS is loan giving to its members. The source of fund is mainly from the BAAC where it can get at $11 \%$ per annum and it offers to the members at $14 \%$ per annum with 3 percent margin which becomes the major income of the NACS. The amount of borrowing from BAAC increased rapidly from 75,000 Baht in $1975 / 76$ to $5,987,330$ Baht in $1984 / 85$. The amount of disbursement of NACS to its members was $7,874,105$ Baht in $1984 / 85$. The repayment of the members to NACS during the year was 5,811,009 Baht. The amount of outstanding principal is $12,402,305$ Baht. The repayment rate of its member is not at the satisfactory level, less than one half of the amount due (see Table 1). The reasons for non-repayment can be listed according to its importance as follows : (1) Misuse of the loan (2) Low prices of farm product (3) Fear for not being able to get new fresh loan.

Besides the credit operation, the NACS also deals with input supply provision as well as marketing of farm products. The NACS owns a 500 metric ton warehouse which is used for the storage of both paddy and chemical fertilizer. The amount of fertilizer sale is about 1-2 million Baht a year. (With the exception of 1982 when it got special quota from the Marketing Organization for Farmers (MOF) which was a part of grant given by the Japanese government for the NWPAP in particular. However, the NACS had to buy this fertilizer from the MOF). The amount of input supply provision is about 223 million Baht (Table 2). There is much room for the increase of the volume of business in this section because the amount of chemical fertilizer purchased through the NACS is about $13 \%$ of the total aggregate demand of farmers in the project area, about 1,500 tons. But it is doubtful whether the NACS will be in the position to compete with the MOF, the state enterprise. The MOF recently opened its warehouse facility in Khon Kaen and sold fertilizer directly to farmers. The NACS had to buy fertilizer from the MOF at the same price as other individual farmers. The amount of consumer product sale by the NACS is also minimal (except for 1984/85 when it dealt with rice selling). The opening of the cooperative store in the villages will certainly increase the sale volume. But the internal control and management efficiency should be increased.

Table 2. The amount of input supply and consumer product provision by the NACS (1,000 Baht).

\begin{tabular}{|c|c|c|c|c|c|}
\hline Year & Fertilizer & Other & farm inputs & Consumer products & Total \\
\hline $\begin{array}{l}1979 / 80 \\
1980 / 81\end{array}$ & 154 & & 28 & $\begin{array}{c}5 \\
-\end{array}$ & 188 \\
\hline $1981 / 82$ & $10(953$ & & 84 & 414 & 11,451 \\
\hline $1982 / 83$ & 1,235 & & 581 & 447 & 2,264 \\
\hline $1983 / 84$ & 1,020 & & 978 & 169 & 2.167 \\
\hline $1984 / 85$ & 679 & & 737 & $1.255^{*}$ & 2,671 \\
\hline
\end{tabular}

Source : Annual Report of NACS, 1980-1985.

*: Including the sale of milled rice which is not a part of the credit and Marketing Linkage Scheme of the CPD.

Marketing of farm product particularly that of paddy is one of the challenging areas for the NACS. There are few agricultural cooperative societies in Thailand 
which are successful in this sort of business. In the past NACS used to do the paddy purchase under the Credit and Marketing Linkage Scheme of the CPD (Table 3). By this scheme agricultural cooperatives could collect loans in kind equivalent to a certain percentage of the loan due from members. For the NACS it was decided to retain 60 percent of the value of sales and giving only 40 percent of cash to the farmers who joined the scheme. It is found that the amount of paddy purchased by the NACS is less than target amount every year. The main reason is that member farmers do not willing to sell the paddy to the NACS because they are afraid of being deducted for debt repayment and they will not get the cash. The other reason is simply because of the lack of transportation facility, the NACS does not have its own truck to transport the paddy from the farm gate whereas the merchants do. The amount of rice purchase being done so far is very minimal comparing with the total production of over 40,000 tons of the farmers in the area. The manager contended that if the NACS was well equipped with the transportation facility and the BAAC was ready to offer the short-term loan, say, about 5 million Baht, the NACS was ready to compete with the local merchants in rice trading. The rice purchased, he proposed, would be shipped to the rice mill of the Khon Kaen Agricultural Cooperative Federation for milling and the NACS by itself would do the wholesaling and retailing business. Under this program all purchase would be made in cash and it would detach from the credit business of the NACS.

\section{The NACS and water management}

The NACS plays the role in water management through the WUGs. Besides the formation and supervision of the groups (which are actually the function of CPD officials who are responsible for the NWPAP) the NACS has to collect the 0 and M fee from the farmers in the project area. This new assignment was given recently, starting in 1984. As far as the WUGs are concerned the NACS has not yet got the complete list of the farmers who are subjected to pay for the 0 and $\mathrm{M}$ fee. Therefore it is not sure how much and what percentage it can collect the fee. More important is the mentality of the NACS which does not want to assume this responsibility. This can be noticed from the annual report of the NACS which did not mention about the MUGs in spite of being officially incorporated into the NACS. It seems that the NACS prefers to limit itself only to the business activities, loan giving or marketing of farm inputs and outputs. The WUG activity which is production related is not much concerned from the NACS administrators' viewpoint. This attitude should be changed

Table 3. Paddy purchase by NACS under the Credit and Markting Linkage Scheme of CPD.

\begin{tabular}{cccccrc}
\hline Year & $\begin{array}{c}\text { Quantity } \\
\text { (Ton) }\end{array}$ & $\begin{array}{c}\text { Amount } \\
\text { (Baht) }\end{array}$ & $\begin{array}{c}\text { Debt } \\
\text { Repayment } \\
\text { (Baht) }\end{array}$ & $\begin{array}{c}\text { Fixed } \\
\text { Deposit } \\
\text { (Baht) }\end{array}$ & $\begin{array}{c}\text { Cash } \\
\text { Payment } \\
\text { (Baht) }\end{array}$ & $\begin{array}{c}\text { Target } \\
\text { Purchase } \\
\text { (Ton) }\end{array}$ \\
\hline $1980 / 81$ & 231 & 738,733 & 98,606 & & 640,127 & 1,000 \\
$1981 / 82$ & 644 & $2,332,550$ & 891.098 & & $1,441,452$ & 1,500 \\
$1982 / 83$ & 436 & $1,374,574$ & 899.608 & 85,700 & 389,266 & 1,500 \\
1983184 & 44 & 118,891 & 114,638 & & 4,253 & 500 \\
$1984 / 85$ & 320 & 821,183 & 649,040 & & 172,143 & 500 \\
\hline
\end{tabular}

Source : Annual Report of NACS, 1981-1985. 
because the WUG should be considered as an integrated part pf the NACS. If the WUG is strengthened, the water management will be more efficient which will eventually result in the increase of productivity. Even though WUG members are not all NACS's members, many of them are while the rest are also potential members. During the current year, the amount of payment of the 0 and $\mathrm{M}$ fee is relatively high, exceed 780,000 Baht. However, if there is no definite rule for punishment to those who do not pay the fee the number of paid members will drastically reduce.

The 0 and $\mathrm{M}$ fee is deducted by $10 \%$ for the administrative cost of the NACS which includes the salary of the clerks, per diem for the committee who inspect the on-farm maintenance works, etc.. In addition to $10 \%$ administrative cost, the NACS pays the head of WUG $4 \mathrm{Baht} / \mathrm{rai}$ in extra as the honorarium for his service. The heads of WUGs are elected every year. Besides the meeting for election of the group head and secretary and the meeting for 0 and $\mathrm{M}$ fee collection there are almost no other activities going on within the WUGs. It was expected that the farm guidance or agricultural extension work should be performed through the WUGs but it had not been realized. There is also difficulty in organizing the group meeting because farmers who are in the same group live in different villages. But if the group becomes active and proves itself beneficial to the productivity of each member, it will become easy to call for a meeting.

\section{CONCLUSION}

Even though the NACS was proposed to be the leading farmer organization in the project area, it has not fulfilled this expectation. The major activity of the NACS is not much different from the typical agricultural cooperatives in Thailand, i. e., giving the agricultural credit to its members. There is a sign for the break-through into other business such as input supply, rice marketing but it is still doubtful whether it can achieve. The inconsistency of the cooperative promotion policy of the government is one of the major obstacle. By vouching the support to the agricultural cooperatives the government also uses other organizations such as the MOF to compete with the cooperatives in selling chemical fertilizer. The presence of the BAAC's role in giving credit to farmers in the project areas in competing with the cooperative makes one doubt whether the authority concerned is really sincere with the above mentioned policy. The NACS also must prove itself to be an efficient organization. The low rate of repayment for the loan of its members should be seriously taken into consideration. The court action should be threatened against willful defaulters.

As for the role of the NACS in water management, the NACS has not so far assumed this responsibility fullfledgedly in spite of being assigned to take care of the WUGs and 0 and $\mathrm{M}$ fee collection. The WUGs in general played an active role in on-farm operation and maintenance of the irrigation facilities. The NACS should cooperate with the RID in the extension program to strengthen the WUG capacity and making the WUG's members realize the importance of maintaining the irrigation facilities. The Land Consolidation Committee should delegate the authority to the NACS for the right to set the rule for punishment the WUG members who do not pay the 0 and $\mathrm{M}$ fee. To make the 0 and $\mathrm{M}$ fee collection effective, the NACS should work out closely with the Land Consolidation Committee to get the complete list of farmers 
in each WUG. The agricultural extension officials should also recognize the roles of the NACS and also its subsidiary organization, namely, WUGs. Instead of going through the DOAE's typical farmer organizations, they should utilize the WUGs for agricultural extension activities. This will greatly help strengthening the WUGs.

\section{ACKNOWLEDGEMENTS}

This work was supported by a Grant-in-Aid for Overseas Scientific Survey (No. 59042007 and 60041051) from the Ministry of Education, Science and Culture, Japan. The authors wish to thank the National Research Council of Thailand for their permission to conduct research in Thailand. We are deeply indebted to the Royal Irrigation Department, the Ministry of Agriculture and Co-operatives of Thailand for their kind help with the field survey.

\section{REFERENCES}

Asian Development Bank 1983 Project Completion Report of the Nong Wai Pioneer Agriculture Project. Asian Development Bank, Bangkok

Nong Wai Agricultural Cooperative Society 1986 Annual Report (for 1981 to 1985). Nong Wai Agricultural Cooperative Society, Khon Kaen (Thailand)

Tejano, A. R. 1983 Operation and maintenance of on-farm facilities through fee collection by the Nong Wai Cooperative. In "Nong Wai Irrigation Management Seminar Report", ed. by Asian Development Bank, Royal Irrigation Department, Khon Kaen (Thailand)

Tejano, A. R. 1983 Termination Report-Strengthening the Nong Wai Agricultural Cooperative Society. Nong Wai Agricultural Cooperative Society. Khon Kaen (Thailand) 